Among the many honorary degrees and awards she received were the University of Tübingen's Lucas Prize for inter-religious understanding, plus Pakistan's highest civilian award; there is also a street in Lahore named after her. Controversy followed the award to her of the Peace Prize (1995) from the German publishing industry, when a number of German intellectuals criticized her for lecturing in Muslim countries with poor human rights records and for disapproving of Salman Rushdie's novel, The Satanic Verses. She was honored by two Festschrifts: Gott is schön und Er liebt die Schönheit/God is Beautiful and He Loves Beauty, ed. Alma Giese and J. Christoph Bürgel (Bern, 1994); and a special issue of the Journal of Turkish Studies (vol. 18, 1994), ed. Maria Eva Subtelny (with bibliography). Her autobiography, Morgenland und Abendland: mein westöstliches Leben, appeared in 2002.

Annemarie Schimmel was dedicated to creating bridges of understanding through which Europeans and Americans could appreciate the spirituality and aesthetic values of Muslim cultures. Her contributions in this entecprise were extensive, and she also had a major impact on Muslims around the world, who saw her as the example of how a non-Muslim could become a sympathetic interpreter of Islam. Her erudition was combined with an extraordinary generosity that was shared among her many students and colleagues. She left an unforgettable impression on all who knew her, and her many contributions will provide an enduring legacy for the field of Islamic studies.

Carl Ernst

University of North Carolina

\title{
John D. Gerhart (1943 - 2003)
}

It is with deep sorrow that I inform you of the passing of our beloved President Emeritus, John D. Gerhart. He died at home in New York City on July 15, 2003 after a valiant battle with cancer.

John was President of the American University in Cairo from September 1998 to September 2002, when he resigned for reasons of health. As President Emeritus, he remained active in the affairs of AUC, raising funds for the new campus and counseling the university administration and the trustees. Upon his retirement, John was prominently recognized for his exemplary accomplishments. President Hosni Mubarak awarded him Egypt's Decoration of Arts and Science, First Class. Dr. Moufid Shehab, Minister of Higher Education and Minister of State for Scientific Research also presented him with a special award for his contributions to education. And in June 2002, John received an Honorary Degree of Doctor of Humane Letters from AUC. His last public function in Cairo was to preside over the official groundbreaking ceremony for AUC's new campus in February 2003, when he introduced the campus design to the distinguished 
guests and assisted the First Lady and AUC alumna, Mrs. Suzanne Mubarak, in laying the cornerstone.

John achieved much during his tenure as AUC President. He personally led the planning for the new campus project and he participated enthusiastically in its development. He equitably resolved long-standing issues affecting the faculty. He initiated many new and innovative academic programs. His unfailing optimism and passionate belief in AUC's mission made him a superb fund-raiser and an eloquent emissary for AUC. He was admired for his high intelligence and his hands-on style of leadership, leavened always with his sense of humor and instinctive understanding of human relations. His humanity inspired all who knew him. He loved and understood Egypt and Egyptians, who reciprocated in kind. He leaves AUC a confident institution, more intellectually and culturally vibrant, and enriched immeasurably by his legacy.

We have all lost a great leader and a good friend.

Paul B. Hannon

American University of Cairo

Walter Oller $(1954-2003)$

Walter Oller, the Middle Eastern Studies Librarian at Brown University, died peacefully this morning after a long struggle with cancer. Walter came to Brown in May of 2001 from New York University, where he had been assistant to the Middle Eastern Studies Librarian. He was also working on a Ph.D. in Middle Eastern Studies at NYU, and he completed and defended his dissertation in the Spring of 2003, while working at Brown. Walter made great progress in building the Library's collections in Middle Eastern Studies, as well as taking on responsibility for Egyptology and Modern Greek Studies. He will be missed by his many friends and colleagues at Brown.

\section{Georges Sabagh (1920 - 2002)}

Georges Sabagh passed away on November 24, 2002 due to pneumonia of the lungs. Colleagues, students, and friends were truly saddened upon hearing the news at MESA 2002 in Washington, DC. Sabagh was Professor Emeritus of Sociology and former Director of the Center for Near Eastern Studies, at UCLA. He was born in Baghdad during King Faisal's reign, grew up in Paris and, after studying briefly in England, came to the US to pursue his higher education. He was a true cosmopolitan, and very much at ease in America, Europe and the Middle East/North Africa, where he spent most of his time. He received $A B$ and MA degrees in Economics in the 1940s, and a Ph.D. in Sociology in 1952, all from the University of California, Berkeley. Before being recruited to UCLA as a 